\title{
JOHN PAUL II'S FIDES ET RATIO AND RELIGIOUS STUDIES IN INDIA
}

\author{
Gnana Patrick \\ University of Madras, India
}

This article argues that Fides et Ratio, the encyclical letter of John Paul II, embodies a unique vision of the relationship between faith and reason, theology and philosophy, and mythos and ratio, which are premised on a dialectical mutuality, ever endeavoring to fulfill one another, even while opening ever new horizons of truth. Faith deepens with the arrival of the propadeutic recta ratio, and reason springs out of its weariness on the intimations of faith. Such a vision would be an apt inspiration for taking up philosophical and religious studies, especially in academic circles. The article shows how a genre of religious studies failed to emerge in the Indian context for various reasons: Some opine that those who introduced modern education in India did not introduce religious studies in the curriculum, and that became the starting point for the absence of the presence of religious studies in Indian academia; others say that the then prevalent 'secularist' ethos Nehruvian era precluded the emergence of religious studies; however, a significant reason to be noted is the apprehension of the Indian mind over the pragmatic orientation of the western-inspired academic studies of religions. This article shows that there could be a holistic way, emergent in Fides et Ratio, to pursue philosophical and religious studies by way of promoting a dialogue between faith and reason, within the horizon of faith, manifest in the consciousness of mythos. An endeavor of religious studies in the Indian academia, embodying this holistic way of dialoguing between faith and reason, is, needless to say, the need of the hour.

\section{INTRODUCTION}

In an article titled, “John Paul II's Papal Encyclicals as Dialectic," Dennis D. Cali $(2009,241)$ argues that the pope's encyclicals "evince a class of discourse" that could be "called dialectic, as contra-distinguished from rhetoric." While developing the argument, Cali situates this form of discourse within the history of the Catholic theological attempt, especially within the Thomistic (combined with Aristotle) one, to bring together faith and reason in a creative and critical dialogue. According to him, the dialectic form refers to a "mode of discourse characterized by dialogue, 
conversation, or disputation" (Cali 2009, 241). It comprises of an initiating (1) premise, assumes a (2) 'determinate Being,' i.e., a clearly stated view of reality, associates with a (3) 'normative categorical view,' and (4) seeks to dispute and disprove opposing viewpoints, as against rhetoric discourse which opens with a 'thesis,' assumes an indeterminate view of reality, goes non-normatively with traditions, and seeks to convince through the continuing discourse.

Cali's ideas bring up a good starting point to discuss John Paul II's encyclical Fides et Ratio (hereafter FR) and relate to the Indian context of religious and philosophical studies. They throw up perceptions that help appreciate the inner dynamics of FR more deeply. While acknowledging the insight embedded in Cali's perception, one may wonder how far can one stretch the binary between 'dialectic' and 'rhetoric,' especially against the contemporary consciousness born out of the philosophical realizations of the language-riddeness of the human experience of reality wherein every discourse is a narrative, rhetoric in a substantive sense. It would imply that even a dialectic is a form of rhetoric, a narrative, a discourse in a disputative mode. The very gestalt of FR as a 'dialectical rhetoric,' if one may wish, situates itself within a long tradition of attempts to bring together faith and reason and promotes a creative, critical, and responsible interaction between them. While doing so, it endeavors to free human experience from extremes of fideism/traditionalism on the one hand and rationalism/ontologism on the other. A 'balanced' integration of faith and reason, according to FR, would take humanity to more significant realizations of greater truths. I surmise that such discourse can meaningfully interact with Indian/Asian religio-philosophical realizations, research, and academic endeavors like 'religious studies' pursued through higher education spaces.

\section{RELIGIOUS STUDIES IN INDIA}

'Religious studies' is a knowledge-perspective that is still in its early stage in India. The very genre of 'religious studies,' embodying a reflective approach to religion, in line with the disciplinary pursuits of knowledge, has not yet sufficiently informed the Indian mind. A 'heavyweight' of traditions and the attendant fascination with mythos are yet to open up a space for religious studies in the subcontinent. A concept like 'religion' presents an enormous complexity while being related to Indian reality. ${ }^{1}$

However, this is not to deny the rigorous pursuits of philosophical inquiries and reflections upon traditions that have been present in this subcontinent from time immemorial. Scholars like K. C. Bhattacharya, Sarvepalli Radhakrishnan, Surendranath Dasgupta, Eric Frauwallner, Karl H. Potter and others, through their voluminous writings, have brought to our awareness the emergence from ancient times of deep metaphysical reflections found in various orthodox or heterodox traditions, philosophical 'systems' and 'devotion'-based 'religious' traditions of this land. ${ }^{2}$

These instances of deep reflections point not merely to the axiological reflexivity ${ }^{3}$ obtained by humanity in this region of the globe but also to the visibility of human reasoning, expressed in argumentations, disputations, and differentiation, as part of a relentless search for 'truth,' the ultimate reality. These forms of reasoning 
eventually flowed down to the making of the typical Argumentative Indian, as in the words of Amartya Sen (2005).

While a stream of such traditions continued to flow through the Indian landscape, they did not yet constitute a genre of critical studies, adequate to be called religious studies. However, a remote beginning of the latter began with the scholars of comparative religion and not less so with the ethnographers of the British colonial dispensation. Max Muller in an earlier period and Mircea Eliade in a later period produced voluminous material on 'religions' of the East and propelled multifaceted intellectual inquiries in the subcontinent, if not in the whole of Asia. A group of scholars, known as the Orientalists, through their strenuous efforts at the collection, classifications, and printing of the available texts, brought up the philosophical heritage of India and contributed significantly to inform the Indian mind of ancient traditions.

Though this initial stage of 'comparative religion' did bring about insights, discussions, debates, and argumentations, they did not yet give birth to an academic study or disciplinary pursuit of religious studies. As Vasutha Narayanan (2015) observes, even the educational policymakers of the colonial times, such as Macaulay, did not consider making religion a subject of academic studies, while other modern subjects like language, literature, law, mathematics, etc. were introduced. This apparently was the beginning of the absence of religious studies, which continued for a long time until some higher educational institutions during the post-colonial era introduced them under Departments of Philosophies, Civilization Studies, Literature, and in some Universities under the name of Departments of Religious Studies. ${ }^{4}$ However, they are very far and few, in a country which has more than 900 Universities! The kinds of studies pursued in these academic institutions, once again, do not lend themselves to be classified uniformly under the genre of religious studies. In not a few institutions, what goes on under the rubric of religious studies is religious 'instructions' and memorizing of religious texts and traditions. However, this is not to deny the serious academic attempts being made in some quarters to study religion or traditions with rigorous methods. ${ }^{5}$

What is very important to note is that besides these limited academic circles, we find a host of voluntary, individual, or institution centered research initiatives to study religion and philosophy in India. First of all, we have native Indian Professorial scholars like T. N. Madan, T. M. B. Mahadevan, Daya Krishna, J.N. Mohanty, and others who have studied or study religion or philosophy and publish widely. While some of them do in the style of systematic expositions, others do it more interpretatively. Secondly, there is a host of scholars of Indian origin but placed abroad in universities or research institutions, like Arvind Sharma, Vasudha Dalmia, Vasudha Narayanan, Ashuthosh Varshney, and others who study Indian religion and philosophy with high levels of specializations. Most of their studies are textual in focus. Thirdly, we have a good number of scholars of Indian origin, placed abroad or present in India, who study the interfaces between religion, philosophy, politics, society, and so on. Ashis Nandy, Partha Chatterjee, and Rajiv Bhargava are some well-known examples. Fourthly, we have a host of foreign scholars, collectives, and institutions who pursue studies on Indian religions and philosophies. An acceptable section among them follows textual studies, branching into studies that fall within religious studies or 
philosophical frameworks, and studies that combine sociological, cultural, and psychological perspectives; yet another good section does field-based empirical research.

Alongside these studies, we find a set of individuals or collectives who pursue studies in relation to contemporary concerns of politics and national identity. Among them, there are those who summate Indian religious traditions, under various specific identities, to constitute a great Indian religion as Hinduism. Moreover, there are others who pursue a polemic agenda of denouncing many of the hitherto extant studies, especially those done by foreign scholars, as anti-Hindu and anti-national, and they are ideologically motivated by a spirit of cultural nationalism to study as well as construct Hinduism as both a national and world religion.

The profile of religious studies emerging from the preceding account brings up specific important concerns regarding the status and role of religious studies in the Indian context today. The first and foremost of the concerns is to address the question of the academic status of religious studies in India. Can India, one of the most populous countries globally, having more than 900 Universities, bring religious studies into its mainline educational curriculum? What are the challenges and prospects facing such a project?

To the question 'why in the first place, India did not come to have religious studies,' several answers are being proposed. As noted above, Vasudha Narayanan, in her study about the status of religious studies in Indian Universities, observed that the colonial educational policymakers, who introduced the modern system of education to India, did not introduce religious studies in the curriculum, and the fallout of this decision continues to inform the educational curriculum until this day. While this could be a reason for the failure to institute religious studies in the first place, it cannot, however, continue to be why it has not been instituted subsequently. Given the fact that India, in its post-independent phase, has come up with new policies on education, it could well have incorporated religion in its academic pursuit. This could have been so, especially when some of the early education-related committees appointed by independent India openly expressed the need for religious and moral instructions for India's youth. For example, a Committee constituted in 1959 by the Government of India on "Religious and Moral Instructions" stated that "many ills that ... our society as a whole is suffering today, resulting in widespread disturbances and dislocation of life, are mainly due to the gradual disturbance of the hold of basic principles of religion on the hearts of our people." 6

That being so, another reason, more in line with the previous one, could be that the policy of religious neutrality adopted by the British Government continued to exist in independent India and that the latter consciously adopted a secular Constitution in which there was no place for public education on religion, i.e., religious studies in public educational institutions. This could certainly be a more concerted reason, given the fact that the Indian Constitution explicitly mentions (Art. 28 ) that publicly funded educational institutions could not have religious education in their curriculum. Moreover, the 'fathers' of the nation, either for reasons of their own secularist orientation or for practical reasons of avoiding conflicts and controversies in dealing with education on different religious traditions, did not even think of introducing religious studies in the mainline curriculum. 
While this could be true to a certain extent, it would still be a limited understanding of the reasons are confined only to the decisions of the 'fathers' of the nation and the Constitution makers, who, after all, were not individuals living in islands. Their understanding of secularism, the immediate concerns of handling religious strife, and, above all, the general religious ethos of the country, combined with an enormity of diverse traditions, weighed upon their minds to inhibit a vision of religious education in public institutions. The Nehruvian era, first of all, went with a certain 'doctrinaire' secularism, which sought to comprehensively separate state and religion, without however adapting the western secularism to the Indian context; secondly, the pressing need of handling religious strife made them think of keeping religion away rather than getting to know them systematically; and, thirdly, the general religious or spiritual ethos, born upon a thick plurality of traditions of the people 'naturally' inhibited an attitude towards objectivizing and studying them.

The last of the reasons mentioned above needs some elaboration. It has always been stereotypically stated that 'India is a land of religions' and that it privileges spiritual goals above 'material' pursuits. 'Land of religions' would mean a land where religiosity takes priority over other concerns in the life and consciousness of the people and where religious traditions proliferate. Some scholars have gone on to state that the Indian mind is characterized by a religio-mythical consciousness in contradistinction to the logo-rational consciousness of the West. For example, Vivekananda glorified the spiritual quest of India, which, unlike the West, forewent material benefits for eternal spiritual goals. ${ }^{7}$

However, others have refuted such a juxtaposing distinction and have pointed out more nuanced differences. Edmund Husserl, for example, would opine that even though both the Greek, the fountainhead of western philosophy, and the Indian philosophies would be involved in explorations of truth, the purpose of such explorations "is different on each side ... Indian thinkers still belong to the so-called 'mythical-religious' mentality whereas only Greece reaches the pure philosophy that implies the autonomy of rational thought." 8 Philosophical reflections or explorations based on human reasoning in India are aimed at end-time purposes of obtaining a release from the karmic cycles ${ }^{9}$ and gaining 'ultimate' liberation, rather than being valuable in themselves or being concerned with temporal gains. As S. K. Maitra (1961, 141) would put it, Hindu Philosophy and culture are not against human reasoning, but "against the values which reason generates, namely, what may be called pragmatic values, which concern themselves only with the economic, political, or social needs of man." Thus, it is possible that the general Indian mind had inhibition towards the academic methodological pursuit of philosophies and religion because of its proclivity towards 'pragmatic' goals.

Another probable hurdle in the academic spread of religious studies could have been the problem of naming those realities, which are usually addressed by religion and philosophy. Some variants of them had been addressed as 'parambara' (traditions) or 'shastra' (philosophy), or 'tarka' (debate) before the advent of the Anglicised categories of religion and philosophy. As Sonia Sikka $(2013,143)$ opines, one does not "assume the modern Western categories of 'philosophy' and 'religion' in one's approach to Indian tradition within academic disciplines." Several scholars have argued that the term 'religion' or its central concepts like 'revelation,' 
'creation,' 'salvation,' etc., do not apply to the Indian realities as they do in western contexts, though similar religious concepts or experiences are prevalent here. For example, Sonia Sikka $(2013,139)$ would argue as follows:

Krishna does 'reveal' his true form to Arjuna, who is then being granted an extraordinary vision of the truth of things, but this does not lead to the Gita being considered a revealed text in the way the Bible is for Christianity, or the Quran for Islam. What we have here is not 'religion' as a distinct sphere of existence involving a special way of believing, but a description of how things are, along with views about how one gets to know how things are and how one should think and act, given that this is how things are.

For Sikka (2013), what are kind of quotidian events in India are analytically brought under the special distinctive sacred realm of religion, with their semantic difference in the West, and this does not cohere well with the Indian ethos. The Durkheimian scheme of 'separation' of the sacred and profane does not take place in the Indian context so as to name something as 'religious' or as something outside the purview of argumentation, debates, and disputation. That is why traditions, whether 'sacred' or 'profane,' have been disputed and counter-traditions initiated in the Indian context with much freedom. Juxtaposing of sacred and profane or faith and reason are not germane to the Indian ethos. Sikka $(2013,141)$ would continue her argument as follows: "I would argue that one of the most serious problems with conceiving of Indian traditions as 'religions' is precisely that the term 'religion' has become mostly synonymous with 'faith.' Faith, moreover, tends to be defined in terms of the various 'others' of reason." While such a difficulty presents itself when naming categories known as religion and philosophy, it is also a fact that these categories have come to exist in academic circles and have gained currency in general usage. Therefore, they may be adopted for their heuristic purposes if not for their essence.

Another apparent factor to inhibit the spread of academic study of religion could have been that the Indian mind treats authority as a valid source of knowledge. As Saksena (1951, 2/38) puts it, "Indian philosophy not only recognizes testimony amongst its sources of knowledge but sometimes even accords it a higher place of importance since by authority alone are certain facts supposed to be known which are not capable of being revealed by other sources... Modern Western philosophy, on the contrary, is founded upon a revolt against authority." The academic study of religion influenced much by the western development of disciplines, might base itself upon empirical evidence or take a phenomenological stance wherein authority or testimony of charismatic individuals counts less.

While these maybe some of the probable hurdles on the academic pursuit of religious and philosophical studies, the need for academic studies on religion and philosophy can never be more urgent and relevant than today. The religiophilosophical terrain in India and Asia needs a creative fertilization today. What we do have now are mostly summations and repetitions than creative philosophical explorations. As Nirmalangshu Mukherji (2002, 931) rightly proposes, a creative philosophical endeavor needs to continuously engage in conversation with the 
leading knowledge-systems and continuously renew human consciousness. In order to be creative and forward-looking, every society needs critical self-examinations; and even when philosophy becomes critical of others, as in the case of Indian philosophy becoming critical of the western religions and philosophies, it needs to be self-critical so as to be faithful to its vocation. As Mukherji $(2002,931)$ opines, "in order for a philosophical tradition to be significantly critical of others, it must develop tools and discourses to be able to examine its own edifice of knowledge critically. Constant self-examination, leading perhaps to self-rejection at times, has been a liberating feature of philosophy in any tradition since antiquity." Indian philosophy has to experience this liberating feature today. Needless to say, academic studies of philosophy and religion can go a long way in this direction.

At this juncture, one also needs to think of academic freedom, which is a desideratum for free philosophical inquiries and religious studies. In the contemporary context of religio-cultural nationalism and identity politics, the casualty oftentimes is the philosophical freedom, i.e., freedom for human reason. Well-known scholars like Romila Thapar have gone to the public with the cry on shrinking space for academic freedom. Amartya Sen is yet another well-known public intellectual who has demanded freedom before thinking of one's identity. Safeguarding the freedom for philosophy, especially from religio-cultural nationalism and oppressive identity politics, would imply that we study religiocultural traditions with the light of reason and promote public conversations on religions and philosophies. Knowing different religious and philosophic traditions in public creates a common discursive field for multi-religious and philosophical conversations.

\section{FIDES ET RATIO}

In such a context of the dire need for academic studies of philosophies and religion on the one hand, and the enduring prohibitive hurdles on the other, one would look for inspirations and motivations from different sources. The document Fides et Ratio (FR) I propose, could be a valuable inspiration or stimulant for getting involved in academic studies to bring together faith and reason in Indian or Asian contexts. While the inspiration can occur on several aspects of FR's document, I wish to dwell upon some aspects that emerge from the very gestalt or the thrust of the whole document rather than its individual themes and dynamics.

The way the document dwells upon the intent of 'dialogue of faith and reason' constitutes the very gestalt of FR. It shows how faith and reason can, and even should, come together without dismantling the horizon of faith, the experience of Divine mystery, manifest in the consciousness of mythos. The very concern of reflecting on the relationship between faith and reason is timely, especially at a time when there is a perceived resurgence of religion all over the world today. Several studies point out this reality of resurgence, along with the emergence of what is known as 'new age religions,' 'public religions', etc. Ours is a time when mythos' human experience is gaining salience even while that of the logos is taking unimaginable strides. Contemporary specialized areas of scientific disciplines take human knowledge to dizzy heights to the point of even causing vertigo of 
consciousness for humanity. Take, for example, the possibilities of gene editing! One would be in for a shock of a millennial kind! Over against this context, the resurgence of religion and its variegated features seem to pose more perplexity than meaningful experiences. Think of the weird forms of religious practices emergent among some sections of the youth population today! It is against such a context a text coming from the Catholic head on the need for harmonizing faith and reason has a deeply inspirational and revitalizing impact.

With its opening sentence, "Faith and reason are like two wings on which the human spirit rises to the contemplation of truth," the document discloses its intent of addressing some of the challenges of our time. With different discursive tropes like 'immanentism,' 'uncertainties,' 'weariness of reason,' 'relativism,' skepticism,' 'nihilism,' etc., it tries to point out that the challenge of the present time is that it suffers from an inability for transcendence, the hope for creative futures. According to the document, such an inability is due to a serious lack in the dialogue of faith and reason/theology and philosophy, due to which what we witness to are either fideism or traditionalism on the one hand and rationalism and nihilism on the other.

The text speaks about a weariness on the part of human reason to search after the truth. The prevalence of relativism and scepticism, which, according to the FR, are the causes of uncertainties and insecurities in the human mind of the present generation, is due to a lack of healthy philosophizing. Contemporary philosophers in India observe that Indian philosophy has been faced with certain weariness in the fields of philosophy. Mukherji (2002) surmises that Indian philosophy stopped growing sometime before the British came to this soil, and today it lacks the vitality to respond to contemporary life-issues of people. If the human spirit has to spread its wings with hope, it needs to be involved in a healthy and genuine dialogue of faith and reason.

Faith, for the document, is, naturally, the Christian faith because it addresses the Christian audience through the bishops. It, therefore, dwells upon the revelation of God in Jesus Christ as the fullness of grace and truth, the embodiments of faith. However, the features of faith and Revelation as enunciated in the document may well share commonalities with other religious traditions as well. As the document says, "This truth, which God reveals to us in Jesus Christ, is not opposed to the truths which philosophy perceives" (FR, 34). "Revelation," for FR, is that which "introduces into our history a universal and ultimate truth which stirs the human mind to ceaseless effort" (FR, 14), and it serves as the "true lodestar of men and women as they strive to make their way amid the pressures of an immanentist habit of mind and the constrictions of a technocratic logic" (FR, 15). Faith that is born out of this revelation is one that "sharpens the inner eye, opening the mind to discover in the flux of events the workings of Providence" (FR, 16). It is "in a sense an "exercise of thought" (FR, 43), and "[I]t is faith which stirs reason to move beyond all isolation and willingly to run risks so that it may attain whatever is beautiful, good and true. Faith thus becomes the convinced and convincing advocate of reason" (FR, 56). These understandings of faith and revelation can appeal well to Indian philosophies and religion because Indian philosophy is one that seeks not merely the truth born out of human perceptions and inference but also the ultimate truth that is born out of intuition and revelation. It is in place to note that FR too acknowledges the presence of such metaphysical quest in the Indian soil: "A great spiritual impulse leads Indian 
thought to seek an experience which would liberate the spirit from the shackles of time and space and would therefore acquire absolute value. The dynamic of this quest for liberation provides the context for great metaphysical systems" (FR, 72). And the document continues to state that in India, "it is the duty of Christians now to draw from this rich heritage the elements compatible with their faith, in order to enrich Christian thought" (FR, 72).

The understanding of reason, as presented in FR, also can share commonalities with philosophical quests everywhere. FR speaks of the innate capacity of human reason to search and arrive at the ultimate truth; it characterizes this capacity as a capacity for transcendence. It is born out of a deep trust in the powers of the human person because they are created by the transcendent God. It is an innate property that enquires into things as they are; it is a resource to search for the meaning and purpose of life; it is a human orientation towards truth, and it can search for the fundamental truths of life. It formulates the first/universal principles of life and leads to the realization of the ultimate truth. Reason, as FR envisions, can search for truth at three levels: one, the experimental level wherein truth is sought through testing, evidence, proof, etc.; second, the philosophical level, wherein truth is sought speculatively, by speculating the first principles of life, the universal and ultimate truth; and the third is at the level of religious truth, understanding the mysteries of revealed truths.

FR surmises that today's human reason is focused upon the experimental truth in generating knowledge on science and technology, neglecting the philosophical and religious. It has failed to gaze at heights because it has wilted under the weight of knowledge; it has failed to explore the philosophy of being but has engrossed in the philosophy of knowledge. "In consequence, the human spirit is often invaded by a kind of ambiguous thinking which leads it to ever-deepening introversion, locked within the confines of its own immanence without reference of any kind to the transcendent. A philosophy which no longer asks the question of the meaning of life would be in grave danger of reducing reason to merely accessory functions, with no real passion for the search for truth" (FR, 81). On the other hand, when pursued as recta ratio, as a genuine rational search, human reason, according to $\mathrm{FR}$, can be the propaeduetic path to faith. It is a path that acknowledges the validity and meaningfulness of revealed truth through the power of human reason, without, however, hurting or damaging the latter. In this way, human reason and faith get related to one another. Such a vision of the relationship between faith and reason could be meaningfully applied to the Indian context, and wherein there is a reluctance to study religion because such a study would apparently damage the faith or tradition. A propaeduetic path, on the other hand, would ensure that reason is pursued, but yet remains to be a path to faith. A path wherein the human endeavor does not replace the transcendental experience would be welcomed in the Indian context.

\section{Authority and Autonomy}

Saksena, as mentioned above, argues that Indian philosophy treats authority as a valid source of knowledge. In addition to perception, inference, and intuitive knowledge, testimony that comes from authority is given great epistemological validity in Indian philosophy. Testimonies of authorities gain an acceptance which 
oftentimes seems to go beyond the scrutiny of independent human reason, logic, and critical thought; or to put it otherwise, the philosophies of authorities, wherein philosophy and authority remain merged together, have salience over a philosophy that seeks autonomy of its own. In practical terms, it has meant that testimony of sages and Gurus have wielded extraordinary influence upon the religious consciousness of Indians, probably also in the whole of Asia.

Very interestingly, the document FR too speaks about the authority of the Magisterium in relation to philosophical matters. It situates itself in relation to human reason/philosophy, not so much as an authority over and above the latter, but a respondent or a critical partner to it. It speaks of "authoritatively exercise(ing) a critical discernment of opinions and philosophies" (FR, 49), especially when philosophies "contradict" the revealed truth forming the core of Christian faith. This 'authoritative exercise' is not from a unilateral position of proclaiming truth, but from a concern of clarifying the Christian Faith, the 'simple faith' of Christian believers, in relation to an emergent plurality of philosophies and opinions. Thus, one would see that the authority in the FR is more functional, a witness to the truth, a service of recta ratio, and not ontological. It is to maintain the autonomy of both faith and reason. As it says, it is to be a corrective to "on the one hand, fideism and radical traditionalism, for their distrust of reason's natural capacities, and, on the other, rationalism and ontologism because they attributed to natural reason a knowledge which only the light of faith could confer" (FR, 52). Again it says, "the Magisterium's interventions are intended above all to prompt, promote and encourage philosophical inquiry" (FR, 51).

FR duly acknowledges the autonomy of human reason and philosophy for the sake of being at the service of truth - diakonia of truth. Right at the beginning of the section on the Magisterium, FR states that the Church does not have a philosophy of its own. Though this could be an equivocal claim, the document goes on to say that it does not have a philosophy of its own precisely to acknowledge the autonomy of philosophy, which is necessary to seek after the truth, which is the primary goal of philosophy and even of theology. In its own words, "philosophy must remain faithful to its own principles and methods. Otherwise, there would be no guarantee that it would remain oriented to truth and that it was moving towards truth by way of a process governed by reason. According to its own principles and methods, a philosophy that did not proceed in the light of reason would serve little purpose. At the deepest level, the autonomy which philosophy enjoys is rooted in the fact that reason is by its nature oriented to truth and is equipped moreover with the means necessary to arrive at truth" (FR, 49). FR envisions that human reason or philosophy, if pursued with autonomy, has the capability to take humanity to truth, even to the ultimate truth. The process helps humanity self-examine its traditions, purify it, and renew its energy for creativity.

\section{Dialogue of Faith and Reason}

The main thrust of FR, as we know, is to promote a dialogue of faith and reason. Right from the beginning of the text, faith and reason are presented as two wings of the human spirit, supportive of each other, containing one in the other, even 
while critically examining one another. One without the other, according to FR, would weaken each other. In the words of the text:

... each without the other is impoverished and enfeebled. Deprived of what Revelation offers, reason has taken side-tracks that expose it to the danger of losing sight of its final goal. Deprived of reason, faith has stressed feeling and experience, and so run the risk of no longer being a universal proposition. It is an illusion to think that faith, tied to weak reasoning, might be more penetrating; on the contrary, faith then runs the grave risk of withering into myth or superstition. The parrhesia of faith must be matched by the boldness of reason (FR, 48).

A lively free expression of faith needs to be matched with a bold reason! Every country has to learn much from this vision of FR. We are witnessing everywhere to extremes, either in the form of curtailing the freedom of faith or the oppressive dominance of tradition. It is the dialogue of the parrhesia of faith and the boldness of reason which can serve as the remedy for such extremes.

As a fruit of the dialogue, it is not merely the extremes that get remedied but also universal values that are cultivated. The FR states that Christianity, reaping the fruits of dialogue of faith and reason, has been endeavoring to dismantle "barriers of race, social status, and gender" and has been proclaiming "the equality of all men and women before God" (FR, 38). The fruits of the dialogue are, thus, to be seen in the egalitarian ordering of human societies, which itself is the result of the way faith and reason dialogue within a "sapiential horizon within which scientific and technological achievements are wedded to the philosophical and ethical values" (FR, 106).

\section{CONCLUSION}

The paper thus argues that Fides et Ratio, a substantive rhetoric embodying a dialectic gestalt, could be an inspiration for taking up philosophical and religious studies, especially in academic circles. It shows how a genre of religious studies failed to emerge in the Indian context for various reasons, especially on account of the apprehension of the Indian mind upon the pragmatic orientation of the westerninspired academic studies. The paper shows that there could be a holistic way to pursue philosophical and religious studies by way of promoting a dialogue between faith and reason, within the horizon of faith, manifest in the consciousness of mythos.

\section{NOTES}

1. For a discussion on this complexity, cf. Lori G. Beaman. 2013. "Reframing Understanding of Religion - Lessons from India,"

2. For a detailed study, cf. Erich Frauwallner 1973, History of Indian Philosophy, Vols. I - II; Karl H. Potter, 1981, Encyclopedia of Indian Philosophies, Vols. I - IX; Sarvepalli Radhakrishnan, 1923, Indian Philosophy, Vols. I - II; Surenderanath Dasgupta, 1922, A History of Indian Philosophy, Vols. I - V. 
3. Axiological reflexivity, as per Karl Jaspers, is a reflective consciousness emergent around eight to third $\mathrm{BC}$, due to which several meta-reflective traditions were born around the globe. Cf. Karl Jaspers, 2011.

4. The University of Madras, for example, has five religious studies departments and one department for Indian philosophy.

5. The Departments of Religious Studies at the University of Madras are cases in point. There are five Departments of Religious Studies (Vaishnavism, Saivism, Jaina Studies, Islamic Studies and Christian Studies) along with a Department for Indian Philosophy.

6. Quoted by A. R. Desai, 1963.

7. Vivekananda, My India - The India Eternal, Kolkota: Sri Ramakrishna Matt, 2008; Fides et Ratio, the papal encyclical, too makes a mention that India has a spiritual quest which provides the framework for metaphysical systems to emerge.

8. As cited in Alexis Pinchard, "Does the concept of theoria fit the beginning of Indian thought?" (Seaford 2016, 118).

9. As Adrados would opine that "The great differences which exist between the philosophies of Greece and India, have their roots in India's insistence on ideas like that of the karma of the samsara, and Salvation and Liberation, which in their turn are based on identification of the Atma and Brahma." (Adrados 1977-78, 6).

\section{REFERENCES}

A. R. Desai, A. R. 1963. National Integration and Religion. Sociological Bulletin, Vol. 12, No. 1 (March 1963), pp. 55, Accessed: October 4, 2019.

Adrados, Francisco R. 1977-78. Indian and Greek philosophy. Annals of the Bhandarkar Oriental Research Institute, Vol. 58/59, 1-8.

Barret, Richard. 2000. The survival of reason: Reflections on 'Fides et Ratio.' New Blackfriars, Vol. 81, No. 955, Special Issue: Fides et Ratio (September), pp. 360376. https://www.jstor.org/stable/43250478. Accessed: 24-12-2019 06:48.

Cali, Dennis D. 2009. John Paul II's papal encyclicals as dialectic. In The Rhetoric of Pope John Paul II. Edited by Joseph R. Blaney and Joseph P. Zompetti. Lanham: Lexinton Books, pp. 233-256.

Cowan, Robert Bruce. 2008. Friedrich Schlegel's indictment of Indian philosophy in "Uber die Sprache und die Weisheit der Indier." The German Quarterly, Vol. 81, No. 3 (Summer), $322-338$.

Dasgupta, Surenderanath. 1922. A History of Indian philosophy, Vols. I - V, Delhi: Motilal Banarsidas Publishers.

Datta, Dhirendra Mohan. 1948. The contribution of modern Indian philosophy to world philosophy. The Philosophical Review, Vol. 57, No. 6 (November), 550 - 572.

Echeverria, Eduard, J. 2004. Once again, John Paul II's Fides et Ratio. Philosophia Reformata. Vol. 69, No. 1, pp. 38-52.

Frauwallner, Erich. 1973. History of Indian philosophy, Vols. I - II, Delhi: Motilal Banarsidas Publishers.

Ganeri, Jonardon. 2009. Intellectual India: Reason, identity, dissent. New Literary History. Vol. 40, No. 2, (Spring), $247-263$. 
Helm, Paul (Editor). 1999. Faith and reason. Oxford: Oxford University Press. Jaspers, Karl. 2011. The origin and goal of history, Abingdon: Routledge.

Lori G. Beaman, Lori G. 2013. Reframing Understanding of Religion - Lessons from India. India International Centre Quarterly, Vol. 40, No. 3/4 (WINTER 2013 - SPRING2014), pp. 35-46, https://www.jstor.org/stable/24394388. Accessed: January 2, 2020.

Maitra, S. K. 1961. Reason in Hindu philosophy: Classical and contemporary. Philosophy East and West. Vol. 11, No. 3 (October), 125 - 142.

Mukherji, Nirmalangshu. 2002. Academic philosophy in India. Economic and Political Weekly. Vol. 37, No. 10 (March 9-15), pp. 931-936, Stable URL: https://www.jstor.org/stable/4411839. Accessed: December 28, 2019.

Narayanan, Vasudha. 2015. The history of the academic study of religion in universities, centres, and institutes in India. Numen. Vol. 62, No. 1, Special Issue - De-Orienting religious studies: Four genealogies of the study of religion in modern Asia, pp. 7-39.

Pajin, Dushan. 1987. The legitimacy of the term 'Philosophy' in an Asian context: The beginnings of Indian philosophy. Journal of Indian Philosophy. Vol. 15, No. 4, 349-362.

Paul II, John. 1998. Fides et Ratio. http://www.vatican.va/content/john-paulii/en/encyclicals/documents/hf_jp-ii_enc_14091998_fides-et-ratio.html.

Pinchard, Alexis. 2016. Does the concept of theoria fit the beginning of Indian thought? In Universe and Inner Self in Early Indian and Early Greek Thought. Edited by Richard Seaford. Edinburg: Edinburg University Press, pp. 118-133.

Potter, Karl H. 1981. Encyclopedia of Indian philosophies, Vols. I - IX, Delhi: Motilal Banarsidas Publishers.

Radhakrishnan, Sarvepalli. 1923. Indian philosophy, Vols. I - II, London: George Allen \& Unwin Ltd.

Saksena, S. K. 1951. Authority in Indian philosophy. Philosophy East and West. Vol. 1, No. 3 (October), pp. 38-49. https://www.jstor.org/stable/1397171. Accessed: December 26, 2019.

Seaford, Richard (Editor). 2016. Universe and inner self in early Indian and early Greek thought. Edinburg: Edinburg University Press, 2016.

Sen, Amartya. 2005. The argumentative Indian - Writings on Indian culture, history and identity. London: Penguin Books.

Sharma, Arvind. 2002. Methodology in religious studies - The interface with women's studies. New York: State University of New York Press.

Sikka, Sonia. 2013. "Teaching religion and philosophy in India. India International Centre Quarterly. Vol. 40, No. 3/4, pp. $131-148$. 